what has been accomplished to permit a realistic assessment of the potential of supersonic commercial aircraft. Would it be feasible to make aircraft flying at Mach 2 or thereabouts sufficiently commodious to carry an economic payload? Is there a possibility that the range of Mach 2 aircraft should be substantially increased? Is the Concorde a possible starting point for the development of an aircraft flying at Mach 3, where the potential benefits of supersonic flight are greater but where other alloys and configurations may be needed? However much the British and French governments may now think that their fingers have been burned, it would be folly for them to overlook the value of the development work already carried out and paid for.

The more difficult question is that of how the aircraft should be brought into commercial service. It will be tempting to suppose that BOAC and Air France should be used as means of demonstrating that Concorde has commercial uses, and to provide the two airlines with a subsidy to keep the aircraft in service for the next few years. This, however, would be a mistaken policy. It is entirely reasonable that the governments should think of writing off the development cost, so that there should be no component of royalty in the price the airlines pay for their aircraft. It is, however, essential that the airlines should not be required to keep on their books uneconomic aircraft which are or become a hidden cost. In the past few months, BOAC, to its credit, has made much of the running in the campaign to bring about reduced fares across the North Atlantic (and it is hoped that the airline will soon extend its fare cutting to other fields). It would be intolerable if the two governments now foisted on their national airlines a scheme for putting Concorde into service which would have the effect of requiring other types of aircraft to shoulder some of the extra cost, for that would imply that ordinary airline passengers would be penalized so as to keep Concorde in the air. If the two governments eventually decide - and there is no reason why they should - that they will put Concorde into service even if the American carriers turn it down, their best course will be to set up a separate operating company, first agreeing to compensate BOAC and Air France for the traffic seduced away from their conventional operations. In such a situation, the true cost of this premature adventure into supersonic flight can be made plain for all to see.

\section{Secrecy in Science}

Mr Airey NeAVE, the chairman of the House of Commons Select Committee on Science and Technology, performed an important public service on Monday, first by persuading the House of Commons that it should debate his committee's proposals for administering publicly supported research and development and then by making his own introduction to the debate on attack on the present traditions of secrecy within the government machine. $\mathrm{Mr}$ Neave is no doubt still smarting from the refusal of the government to make public the Docksey report on the National Research and Development Corporation, eventually published by the Select Committee itself, and the Vinter report on the future of nuclear power in Britain, still unpublished. But these are only the tips of icebergs. The British government's administration of research and development in Britain is almost exclusively determined by the advice of committees which still operate in confidence and which have the effect not merely of obscuring the reasons why governments make particular decisions but also of preventing those individuals who take part in the advisory process, and who are usually the best informed, from engaging in the kind of public discussion of public issues which might bring enlightenment. $\mathrm{Mr}$ Neave is entirely right to emphasize the need for more open discussion.

Mr James Prior, the new Lord President of the Council, had only the weakest of replies on Monday. He held, somewhat implausibly, that it would be impossible to persuade distinguished scientists to give advice at all if they knew that what they said might eventually be published. But might it not be more sensible of him to turn the argument round, and to say that advice which is given only secretly is likely often to be unhelpful and even ill-considered? Worse still, there is of course a danger that if governments like the British neglect to cultivate the scientific community as an important constituent of public life, especially when both the government and the opposition are claiming that steps must be taken to make individuals feel more intimately involved in the making of decisions which affect them directly, the result will be still further to depress their spirits. It is reprehensible that decisions about science and technology should be made behind closed doors.

\section{Years Ago}

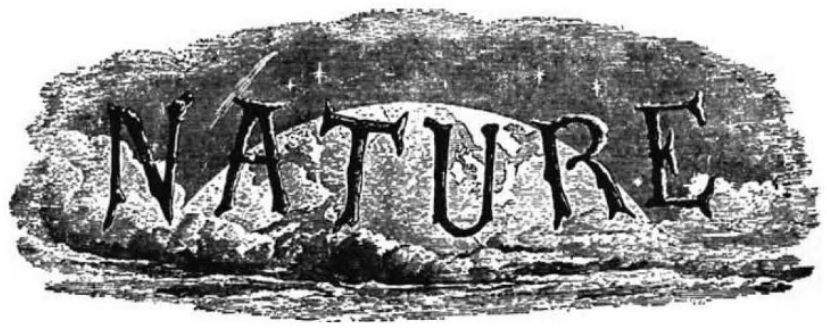

\section{THE NATIONAL HERBARIA MEMORIAL}

$\mathrm{W}^{\mathrm{E}}$ are glad to be able to lay before our readers the reply to the memorial to Mr. Gladstone, signed by so many eminent botanists, which appeared in NATURE for January 16. The answer is in every respect satisfactory :-

"Treasury Chambers, January 23, 1873

"Sir,-The Lords Commissioners of Her Majesty's Treasury have had before them your letter of the 3 rd instant, and the Memorial enclosed in it from various gentlemen engaged in the pursuit of botany or in instruction therein, with respect to the transfer to the branch of the British Museum about to be constructed at South Kensington,- of the scientific collections and library now existing at the Royal Gardens at Kew.

"Their lordships desire me to request that you will inform the memorialists that Her Majesty's Government have not formed the intention of removing the collection to South Kensington, and that-should anything lead them hereafter to entertain the idea, they will take care that ample notice shall be given, and that the judgment of the persons most accomplished in botany shall be fairly weighed in the first instance.

"I am, Sir, your obedient servant, "WILLIAM LAw

"The Rev. M. J. Berkeley, Sibbertoft, "Market Harborough"

From Nature, 7, 243, January 30, 1873. 